\title{
Dartos flap coverage of the neourethra following repair for primary hypospadias, reoperative hypospadias and urethrocutaneous fistulas. It is a safe approach ${ }^{1}$
}

\author{
Emprego de um retalho pediculado do músculo dartos para cobertura da neouretra na cirurgia \\ primária de hipospádias, reoperações de hipospádias e correção de fístulas uretrocutâneas
}

\author{
Hayrettin Ozturk ${ }^{\mathrm{I}}$

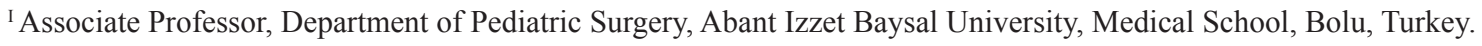

\begin{abstract}
Purpose: Urethrocutaneous fistula and neourethral dehiscence are frequently seen complications of hypospadias surgery requiring reoperation. In this study we report the experience of one surgeon with dartos flap coverage in primary hypospadias, reoperative hypospadias and urethrocutaneous fistulas repair. Methods: A total of 23 patients underwent hypospadias and urethrocutaneous fistulas repair from January 2006 to May 2009. Fourteen patients were operated on for primary hypospadias repair at our institution and 9 patients were admitted for hypospadias complications such as failed hypospadias repair and urethrocutaneous fistula. In all the patients, the dartos flap was dissected and transposed to cover the neourethra. Operative results were recorded. Results: The primary surgical procedure was a one-stage repair in $61 \%(n=14)$; tubularised incised plate (TIP) urethroplasty in 43\% $(n=6)$ and a Mathieu procedure in $57 \%(\mathrm{n}=8)$. Urethrocutaneous fistulas complicating the previous initial hypospadias repair were anterior in $33 \%(\mathrm{n}=2)$, middle in $33 \%(n=2)$ and proximal in $33 \%(n=2)$. Repair of the fistula was successful on the first attempt in all patients. The reason for redo surgery in 3 patients was complete dehiscence and the patients had distal shaft hypospadias. Conclusion: Dartos flap coverage of the neourethra seems to be an effective method of reducing the fistulous complication rate following primary and secondary hypospadias repair.
\end{abstract}

Key words: Hypospadias. Fistula. Surgical Flaps. Scrotum.

\section{RESUMO}

Objetivo: Fístulas uretrocutâneas e deiscências são complicações frequentes na cirurgia das hipospádias necessitando reoperações. Este estudo é baseado na experiência pessoal de um cirurgião utilizando um retalho pediculado do músculo dartos para cobertura da neouretra na correção primária de hipospádias, reoperações de hipospádias e correção de fístulas uretrocutâneas. Métodos: Vinte e três pacientes foram operados sendo 14 submetidos a cirurgia primária de hipospádia e 9 a reoperações por insucesso da correção primária ou por fístulas uretrocutâneas. Em todos os pacientes, um retalho pediculado do músculo dartos foi mobilizado e utilizado para recobrir a neouretra. Resultados: Para a cirurgia primária da hipospádia foi utilizada técnica de correção em um só tempo (n=14): uretroplastia tubularizada com incisão da placa (TIP) em 43\% $(n=6)$ e técnica de Mathieu em $57 \%(n=8)$. As fístulas uretrocutâneas resultantes de correções primárias anteriores eram de localização anterior em $33 \%(n=2)$, média em $33 \%(n=2)$ e proximal em $33 \%$ ( $n=2)$. A correção das fístulas uretrocutâneas resultou em sucesso em todos os pacientes. Três pacientes necessitaram de reoperação por deiscência completa e em todos a hipospádia era distal. Conclusões: O emprego do retalho pediculado do músculo dartos para recobrir a neouretra é um método eficaz que reduz a incidência de fístulas em cirurgias primárias e nas reoperações de hipospádias.

Descritores: Hipospadia. Fistula. Retalhos Cirúrgicos. Escroto.

${ }^{1}$ Research performed at Department of Pediatric Surgery, Abant Izzet Baysal University, Medical School, Bolu, Turkey.

\section{Introduction}

With an incidence of 1:300, hypospadias is one of the most common genital anomalies in male newborns ${ }^{1,2}$. Hypospadias is defined as an anomaly (hypo- or dysplasia) involving the ventral aspect of the penis ${ }^{2,3}$.

The position of the urethral meatus in hypospadias can be glanular, along the penile shaft, scrotal, or perineal ${ }^{4}$. In current practice, hypospadias repairs are performed as outpatient procedures with high success rates ${ }^{5}$. Despite the use of optical magnification, fine suture material and modern techniques, urethrocutaneous fistula or neourethral dehiscence was the most troublesome complication. These problems are the main difficulty in re-operations, because in these cases urethral reconstruction is required, but only a small amount of penile foreskin is available. On the other hand, the vasculature of previously operated tissues may be suboptimal, resulting in further complications ${ }^{5,6}$. In this study we report the experience of one surgeon on dartos flap coverage in primary hypospadias, reoperative hypospadias and urethrocutaneous fistulas repair. 


\section{Methods}

A total of 23 patients underwent hypospadias and urethrocutaneous fistulas repair from January 2006 to May 2009 at our clinic. Fourteen patients were operated on for primary hypospadias repair at our institution and 9 patients were admitted for hypospadias complications such as failed hypospadias repair and urethrocutaneous fistula (Figure 1). All of the operations were performed by the same surgeon.
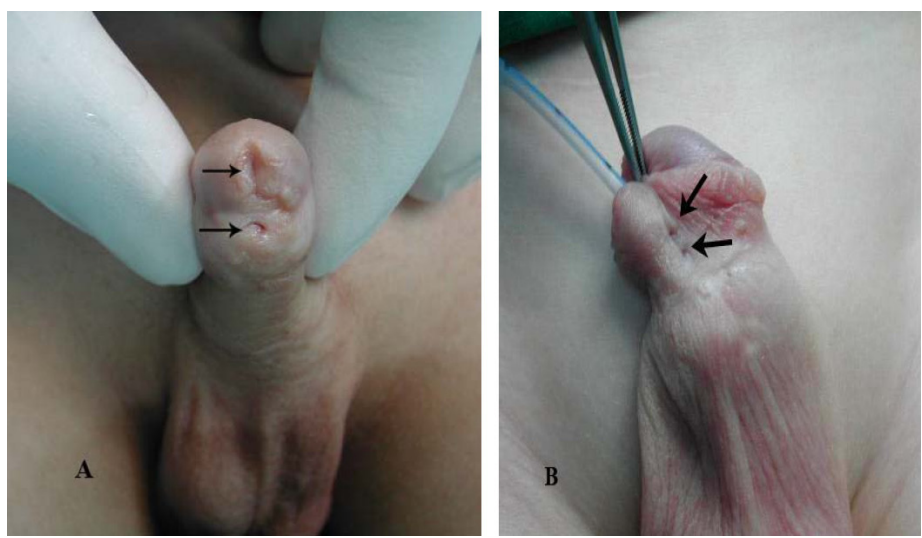

FIGURE 1 - A. Failed hypospadias repair. B. Urethrocutaneous fistulas

After general anesthesia, a stay suture was placed through the glans for traction. Then, the penis was degloved and any meatal stenosis or fistula opened widely, to prevent subsequent stricture formation. An artificial erection was carried out for ventral curvature, as a necessary step. Penile curvature correction by dorsal plication, as described by Mingin and Baskin was required in only 1 patient $^{7}$. Also, a tourniquet to the root of the penis was used for hemostasis in all patients. plasty

\section{Surgical technique for Snodgrass and Mathieu urethro-}

The tubularized incised plate urethroplasty (TIPU) was carried out using the technique described by Snodgrass ${ }^{8}$. Parallel incisions separated the glans wings from the urethral plate and the plate was incised in the mid-line. For urethroplasty in Mathieu procedure ${ }^{9}$, a parameatal-based skin flap was created by circumscribing the ventral paraurethral and parameatal penile skin. After complete mobilization and outlining of the urethral plate and skin flap, urethroplasty was completed by onlay of the parameatal skin flap over a $6 \mathrm{~F}$ urethral catheter with 7-0 Polydioxanone suture in a running subcuticular manner. In all of the patients, double dartos flap from the preputial hood was dissected and transposed to cover the neourethra ventrally and 7-0 Polydioxanone was used for suturing (Figure 2). Then, the subcutaneous tissue and skin are closed using 6-0/7-0 Polydioxanone suture material.
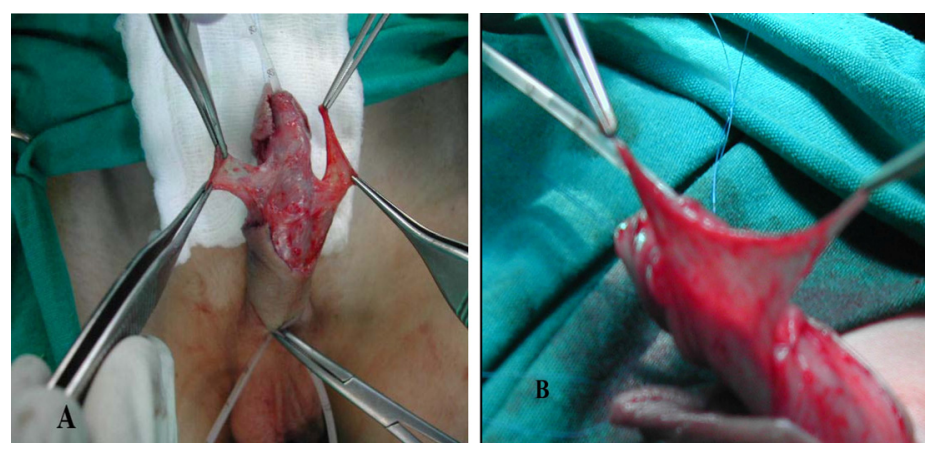

FIGURE 2 - A. Double dartos flap coverage of proximal neourethra in progress. B. Ventral transposition of the longitudinal dorsal dartos flap

\section{Surgical technique for urethrocutaneous fistula repair}

All repairs were performed at least 6 months after the original hypospadias repair. A $6 \mathrm{~F}$ stent was passed into the bladder for post operative urinary diversion. The urethrocutaneous fistula tract is mobilized down to the urethra by sharp dissection after a circumferential incision around the skin opening. Meticulous dissection is important to prevent the formation of a hole in the tract that might invalidate the technique. In all the patients with urethrocutaneous fistula, the repairs were performed using 7-0 polydiaxanone suture material, and the repairs were covered with a second layer of vascularized local tissue flap (dartos). The subcutaneous tissue and skin are then closed using 6-0/7-0 Polydioxanone suture material.

Suprapubic diversion was not used for any of the patients. The catheter within the urethra was secured distally to the glans with the traction suture. The operation was finished by the application of gauze a compression dressing to the penis. The dressings were opened on the fifth and seventh postoperative day. The patients were hospitalized for approximately 2 days postoperatively, sometimes extending to 5-7 days depending on the family's preference. A broad spectrum antibiotic for prophylaxis was given throughout the hospitalization. Catheter was removed after seven days. The patients underwent follow-up examinations the first week, first month, and 6 months after discharge, with more frequent examinations as required.

\section{Results}

The patient age range was 6 months to 10 years (mean 4.3 years). Of the 23 patients, 14 (61\%) had primary hypospadias and $9(39 \%)$ had secondary hypospadias undergone hypospadias repair in another center previously. Of the 14 primary patients, 12 $(86 \%)$ had distal shaft hypospadias and $2(14 \%)$ had mid-penile hypospadias. Of the 9 secondary patients, $6(67 \%)$ had 1 -to 3 urethrocutaneous fistulas and $3(23 \%)$ patients had previously undergone 1-to 3 failed hypospadias repair. Two of these patients were uncircumcised and a patient was circumcised.

The primary surgical procedure was a one-stage repair in $61 \%(\mathrm{n}=14)$; tubularised incised plate (TIP) urethroplasty in $43 \%(\mathrm{n}=6)$ and a Mathieu procedure in $57 \%(\mathrm{n}=8)($ Figure 3$)$. 


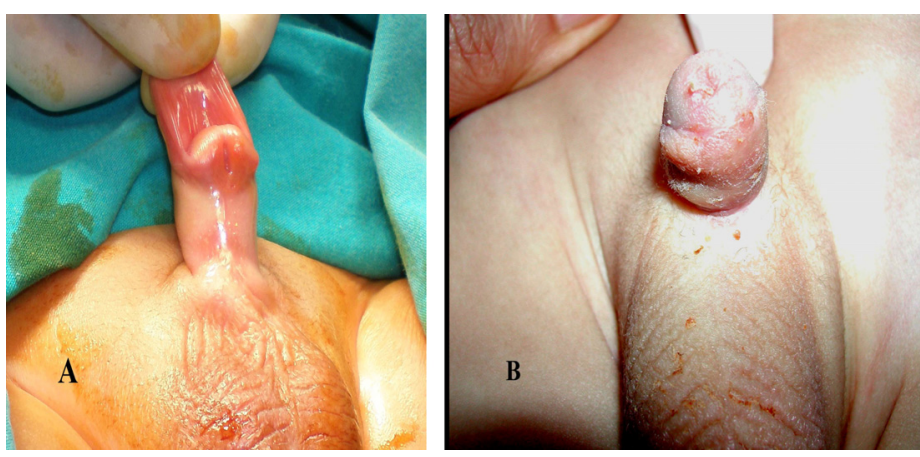

FIGURE 3 - A. Distal shaft hypospadias. B. The Mathieu procedure: 2-month postoperative view

Urethrocutaneous fistulas complicating the previous initial hypospadias repair were anterior in 33\% $(\mathrm{n}=2)$, middle in $33 \%(n=2)$ and proximal in $33 \%(n=2)$. Repair of the fistula was successful on the first attempt in all patients.

The reason for redo surgery in 3 patients was complete dehiscence and the patients had distal shaft hypospadias. The previous techniques utilized Mathieu repair in one, ThiershDuplay in one and unknown in one. After the primary evaluation, Mathieu procedure was performed for correction of complications related to the previous hypospadias surgery. Uncircumcised in 2 patients, the dartos flap from the preputial hood was dissected and transposed to cover the neourethra ventrally. In the other 1 patient, the repairs were covered with a second layer of vascularized local tissue flap (dartos). These patients were treated successfully with Mathieu repairs.

None of the patients developed meatal stenosis and neourethral caliber and cosmetic appearance were satisfactory in all patients in the follow-up period of this study.

\section{Discussion}

Hypospadias surgery is challenging. The fact that there are wide variations in the presentation and extent of malformations as well as tissue characteristics existent makes every hypospadias individual and a proposal of a universal comprehensive algorithm for hypospadias repair difficult.

The "TIPU" technique was first described by Snodgrass ${ }^{8}$ following excellent cosmetic results when this technique was used on 16 patients with distal hypospadias without any complications. The technique can be performed for proximal, distal, primary, and secondary hypospadias cases. In the primary cases, a $0 \%-9 \%$ fistula complication rate and $0 \%-21 \%$ meatal stenosis rate have been reported ${ }^{4}$. Parameatal-based flap urethroplasty (the Mathieu procedure) first described by Mathieu ${ }^{9}$ is another commonly used standard technique with a complication rate of less than $4 \%$ in different series in recent years ${ }^{10,11}$. By this technique, an acceptable meatal caliber could be achieved, and there is no concern about the distal extension of neourethra to prevent meatal stenosis ${ }^{12}$. Urethrocutaneous fistulae after hypospadias surgery have been a serious problem for patients and surgeons since repair was first attempted $^{13}$. In order to prevent fistulas, particularly healthy tissue from different areas is used to cover the neourethra using different techniques. Sozubir and Snodgrass used a dorsal dartos flap that was transposed to the ventral aspect of the penis over a buttonhole technique ${ }^{2}$. Recent reports have revealed that double dartos flap coverage of the neourethra is superior to single flap coverage for the prevention of urethrocutaneous fistula after tubularized incised plate urethroplasty ${ }^{14}$. Further, glanular torsion, a risk with single flap coverage does not happen with double dartos flap coverage. Conventionally, flap coverage has been provided over the entire neourethra ${ }^{15}$. The primary hypospadias cases reported in the present series had distal shaft and mid-penile hypospadias. None of our 14 patients with primary hypospadias operated by TIPU and Mathieu developed an urethrocutaneous fistula. In both techniques, the neourethra was covered with double dorsal dartos flap. We believe that dorsal dartos flap coverage of the neourethra to prevent fistula development may have an important role. Additionally, it is clear that to become more effective in the application of surgical techniques, clinical knowledge and surgical experience is important.

Primary hypospadias repairs are associated with failure rates of 5-20\% depending upon the type of procedure performed, location of original meatus and quality of tissue available for the initial repair ${ }^{16}$. The challenges of performing a secondary hypospadias repair include lack of healthy or adequate amount of local tissue with which to create flaps for both replacement and/or coverage of the defective urethra and, resurfacing the penile shaft ${ }^{17}$. The ideal surgical method for complex penile repairs has not been established. Wheeler and Malone ${ }^{18}$ and Keramidas and Soutis ${ }^{19}$ reported that meatus-based flaps could be used as a salvation operation with high success rates, $83.3 \%$ and $100 \%$, respectively. Bar-Yosef et al. ${ }^{20}$ reported that they achieved $74 \%$ success in their series of 34 patients reoperated using the Mathieu technique. Karabulut et al. ${ }^{21}$ reported that success rate was $84.2 \%$ in the group consisting of 57 patients who were reoperated using the Mathieu technique. We may consider not only the experience acquired by frequent use of the Mathieu technique in our clinic but also fastidiousness in choosing reoperative cases in whom this technique is applicable as the reason for this success. The sensitivity in case selection for this technique is that the urethral plate is narrow, ventral skin is soft and has less scarring, and the skin around the meatus is soft and unscathed ${ }^{21}$, as was in our cases. In this study, two patients with secondary hypospadias were uncircumcised and 1 patient was circumcised. All of the patients with secondary hypospadias were repaired by using the Mathieu technique. In uncircumcised patients, the neourethra was covered with dorsal dartos flap. In one circumcised patient the neourethra was covered by local dartos flap.

Urethrocutaneous fistula is one of the most frequently seen complications of hypospadias surgery requiring reoperation ${ }^{22}$. The incidence of fistula development has varied from $4 \%$ to $20 \%$ in larger series ${ }^{23,24}$. Factors such as obstruction at the distal part of the new urethra, tissue ischemia, and postoperative infection can lead to urethrocutaneous fistula development after hypospadias surgery. The frequency of fistula formation has decreased as a result of surgeon experience, improvement in operative technique, use of appropriate suture materials and instruments, and coverage of the operation area with well-vascularized tissue ${ }^{25}$. Sunay et al. ${ }^{25}$ suggested that the suture lines should not overlap, a second dartos flap should be used between the suture lines, and improved procedures must be performed in the case of the presence of urethral stricture and diverticulum. The principles we pursue during the surgery are as follows: checking the patency of the meatus, dissecting the fistula with its tract up to the base, and the repairs were covered with a second layer of vascularized local tissue flap (dartos). 
It is clear that to become more effective in the application of surgical techniques, clinical knowledge and surgical experience is important. In our limited study with a small number of patients, we conclude that in experienced hands, the TIPU and Mathieu techniques are valuable single-stage methods, due to its low complication rate as well as its satisfactory functional and cosmetic results in distal and midpenile hypospadias cases. Dorsal dartos flap coverage of the neourethra seems to be an effective method of reducing the fistulous complication rate following TIPU and Mathieu repair for distal and midpenil hypospadias.

Redo hypospadias and urethrocutaneous fistula repairs are challenging and occasionally humbling. Using the Mathieu urethroplasty particularly in uncircumcised patients is a suitable method for treating the re-operative cases. In all patients, an acceptable meatal caliber was achieved. In patients with urethrocutaneous fistula, local dartos flap is critical. From the small number of cases in this study, further studies involving a greater number of reoperative hypospadias patients would be valuable to confirm these results.

\section{Conclusions}

Dartos flap coverage of the neourethra seems to be an effective method of reducing the fistulous complication rate following primary and secondary hypospadias repair.

\section{References}

1. Perovic S. Atlas of congenital anomalies of the external genitalia. Belgrad, Yugoslavia, Refot-Arka; 1999.

2. Djakovic N, Nyarangi-Dix J, Ozturk A, Hohenfellner M. Hypospadias. Adv Urol. 2008;650135.

3. Baskin LS, Ebbers MB. Hypospadias: anatomy, etiology, and technique. J Pediatr Surg. 2006;41(3):463-72.

4. Akbiyik F, Tiryaki T, Senel E, Mambet E, Livanelioglu Z, Atayurt H. Clinical experience in hypospadias: results of tubularized incised plate in 496 patients. Urology. 2009;73(6):1255-7

5. Al-Sayyad A, Pike JG, Leonard MP. Redo hypospadias repair: experience at a tertiary care children's hospital. Can Urol Assoc J. 2007;1(1):47-51. 6. Mousavi SA. Use of tubularized incised plate urethroplasty for secondary hypospadias repair or repair in circumcised patients. Int Braz J Urol. 2008;34(5):609-14

7. Mingin G, Baskin LS. Management of chordee in children and young adults. Urol Clin North Am. 2002;29(2):277-84

8. Snodgrass W. Tubularized, incised plate urethroplasty for distal hypospadias. J Urol. 1994;151(2):464-5.

9. Hadidi AT, Azmy AF. Hypospadias surgery: an illustraded guide. Berlin, Germany: Springer; 2004.

10. Yesildag E, Tekant G, Sarimurat N, Buyukunal SN. Do patch procedures prevent complications of the Mathieu technique? J Urol. 2004;171(6 Pt 2):2623-5.

11. Hayashi Y, Sasaki S, Kojima Y, Maruyama T, Tozawa K, Mizuno K, Kohri K. Primary and salvage urethroplasty using Mathieu meatal-based flip-flap technique for distal hypospadias. Int J Urol. 2001;8(1):10-6.

12. Aminsharifi A, Taddayun A, Assadolahpoor A, Khezri A. Combined use of Mathieu procedure with plate incision for hypospadias repair: a randomized clinical trial. Urology. 2008;72(2):305-8.

13. Malone PR. Urethrocutaneous fistula: preserve the tract and turn it inside out: the PATIO repair. BJU Int. 2009;104(3):550-4.

14. Kamal BA. Double dartos flaps in tubularized incised plate hypospadias repair. Urology. 2005;66(5):1095-8.

15. Kureel SN, Vasudeva P, Sinha SK, Dalela D. "Limited" double dorsal dartos flap coverage. An effective alternative to conventional flap coverage of the neourethra following Mathieu repair for subcoronal hypospadias. Int Urol Nephrol. 2008;40(3):569-72.

16. Mouriquand P, Mure PY, Zeidan S, et al. Management of failed hypospadias repairs. In: Hadidi AT, Azmy AF (eds). Hypospadias surgery. New York: Springer; 2004.

17. Eliçevik M, Tireli G, Demirali O, Unal M, Sander S. Tubularized incised plate urethroplasty for hypospadias reoperations in 100 patients. Int Urol Nephrol. 2007;39(3):823-7.

18. Wheeler R, Malone P. The role of Mathieu repair as a salvage procedure. Br J Urol. 1993;72(1):52-3.

19. Keramidas DC, Soutis ME. Urethral advancement, glanduloplasty and preputioplasty in distal hypospadias. Eur J Pediatr Surg. 1995;5(6):348-51. 20. Bar-Yosef Y, Binyamini J, Matzkin H, Ben-Chaim J. Salvage Mathieu urethroplasty: reuse of local tissue in failed hypospadias repair. Urology. 2005;65(6):1212-5.

21. Karabulut A, Sunay M, Erdem K, Emir L, Erol D. Retrospective analysis of the results obtained by using Mathieu and TIP urethroplasty techniques in recurrent hypospadias repairs. J Pediatr Urol. 2008;4(5):359-63.

22. Santangelo K, Rushton HG, Belman AB. Outcome analysis of simple and complex urethrocutaneous fistula closure using a deepithelialized or full thickness skin advancement flap for coverage. J Urol. 2003;170(4 Pt 2):1589-92.

23. Rushton HG, Belman AB. The split prepuce in situ onlay hypospadias repair. J Urol. 1998;160(3 Pt2):1334-6.

24. Asopa HS. Newer concepts in the management of hypospadias and its complications. Ann R Coll Surg Engl. 1998;80 (3):161-8.

25. Sunay M, Dadali M, Karabulut A, Emir L, Erol D. Our 23-year experience in urethrocutaneous fistulas developing after hypospadias surgery. Urology. 2007;69(2):366-8.

\section{Correspondence:}

Hayrettin OZTURK

Conflict of interest: none Financial source: none

Abant Izzet Baysal University, Medical School

Department of Pediatric Surgery

14280 BOLU, Turkey

Phone: (90 374)253-4656 / 3220

Fax: (90 374)253-4615

Received: September 17, 2009

ozturkhayrettin@hotmail.com

Review: November 19, 2009

Accepted: December 16, 2009

\section{How to cite this article}

Ozturk H. Dartos flap coverage of the neourethra following repair for primary hypospadias, reoperative hypospadias and urethrocutaneous fistulas. It is a safe approach. Acta Cir Bras. [serial on the Internet] 2010 Mar-Apr;25(2). Available from URL: http://www.scielo.br/acb 